\title{
KEBIJAKAN PENANGGULANGAN KEKERASAN TERAHADAP ANAK DI KOTA AMBON
}

\author{
Yonna Beatrix Salamor ${ }^{1}$, Judy Marria Saimima ${ }^{2}$ \\ ${ }^{1}$ Program Studi Ilmu Hukum, Universitas Pattimura \\ Email: yonnahukum@gmail.com \\ 2 Program Studi Ilmu Hukum, Universitas Pattimura \\ Email: judymarria@gmail.com
}

\begin{abstract}
At present, crime frequently occurs in the community. One of the most common crimes are criminal acts of violence towards children. Common acts of violence towards children are often in the form of physical, psychological, and sexual violence. Various known cases of violence towards children are not limited to major cities in Indonesia, but also to other smaller cities and areas with major eastern culture influence. One area with high level of violence towards children is in the Maluku Province, specifically Ambon City. The purpose of this study is to study the forms of countermeasure against violence towards children that occurs in Ambon City. The method used in this study is Juridical Empirical, in which data is obtained not only from field research but also through various literature. Based on research, according to data from Ambon Island and Lease Islands Police from 2017 it was found that the forms of violence include violence towards children, sexual abuse of children, sexual intercourse with children and abortion amounting to106 cases.
\end{abstract}

Keywords: Policy for Countermeasures, Violence, Children, Ambon City

\begin{abstract}
ABSTRAK
Dewasa ini banyak tindak pidana yang terjadi di kalangan masyarakat. Salah satu tindak pidana yang sering terjadi, yaitu tindak pidana kekerasan terhadap anak. Tindak kekerasan terhadap anak saat ini kerap terjadi baik merupakan kekerasan secara fisik, psikis maupun seksual. Berbagai kasus kekerasan terhadap anak yang muncul kepermukaan, ternyata tidak hanya terjadi di kota-kota besar di Indonesia tetapi banyak juga terjadi di kota-kota kecil atau daerah yang mash kental dengan budaya ketimuran. Salah satu daerah yang termasuk banyak terjadi kekerasan terhadap anak adalah di Provinsi Maluku khususnya Kota Ambon. Tujuan penelitian ini adalah mengetahui bentu-bentuk penanggulangan kekerasan terhadap anak yang terjadi di Kota Ambon. Metode yang digunakan dalam penelitian ini adalah Yuridis Empiris, dimana data yang didapat tidak hanya dari penelitian lapangan tetapi juga melalui berbagai literatur. Berdasarkan penelitian, maka ditemukan dalam tahun 2017 menurut data unit PPA Polres P. Ambon \& P.P. Lease bentuk kekerasan yang terjadi antara lain kekerasan terhadap anak, percabulan terhadap anak, persetubuhan terhadap anak dan aborsi dengan jumlah kasus 106 kasus.
\end{abstract}

Kata kunci: Kebijakan Penanggulangan, Kekerasan, Anak, Kota Ambon

\section{PENDAHULUAN}

Perkembangan masyarakat senantiasa membawa dampak tersendiri terhadap proses pembangunan suatu bangsa. Indonesia adalah negara hukum yang menjunjung tinggi harkat dan martabat manusia serta menjamin kesejahteraan tiap-tiap warga negaranya, termasuk menjamin perlindungan anak, karena anak juga memiliki hak-hak yang termasuk dalam hak asasi manusia. Anak adalah suatu karunia Tuhan Yang Maha Esa yang dalam dirinya juga terdapat suatu harkat dan martabat yang dimiliki oleh orang dewasa pada umumnya, maka anak juga harus mendapatkan suatu perlindungan khusus agar kelak dapat tumbuh dan berkembang dengan baik. Anak adalah generasi muda penerus bangsa serta berperan dalam menjamin kelangsungan eksistensi suatu bangsa dan negara itu sendiri.

Pelanggaran hak asasi manusia sering terjadi saat ini. kemajuan ilmu pengetahuan dan teknologi, globalisasi, dan kemajuan industry telah melunturkan nilai-nilai kasih sayang dan penghormatan serta penghargaan seseorang terhadap nilai etis, etika, moral dan agama, sehingga seseorang dengan mudah menyakiti orang lain dengan tujuan tertentu. Oleh sebab 
itu, banyak pelanggaran hak asasi terjadi dalam berbagai bentuk, umumnya dalam bentuk kekerasan fisik maupun psikis. Kekerasan dapat terjadi pada siapa saja. Umumnya kekerasan terjadi pada orang-orang yang lemah, seperti anak, perempuan dan orang tua lansia. Kekerasan biasanya didominasi orang-orang kuat dan berkuasa. Kekerasan dikatakan melanggar hak-hak asasi karena kekerasan merampas hak-hak kebebasan, hak-hak untuk hidup dengan baik dan mendapatkan perlakuan yang baik pula.

Pada umumnya masyarakat menganggap kekerasan dalam rumah tangga terhadap anak sebagai urusandapur satu keluarga. Orang tua juga tidak sedikit yang beranggapan bahwa anaknya adalah hak milik dan tanggungjawabnya sehingga ia berhak melakukan apa saja, termasuk memukul dengan kesal sehingga anak mengalami luka serius yang dapat menyebabkan anak meningal dunia atas nama mendidik, membina dan melaksanakan tugasnya sebagai orang tua. Anak dapat dipukul, dihukum, dimarahi, dicubit, dijewer, disiksa diperkosa.

Tindak kekerasan pada anak di rumah dilakukan oleh orang, keluarga atau orang disekitar anak. Sebab-sebab tindak kekerasan dilakukan karena ada perilaku anak yang menjengkelkan orang tua, sehingga orang tua mudah memukul fisik anaknya dan mengeluarkan kata-kata verbal yang menyakiti perasaan. Tindakan kekerasan orang tua pada anak sangat mudah dilakukan bilamana orang tua sedang menghadapi masalah dan kurang dapat mengendalikan emosinya dengan baik. akibat pemukulan fisik dan psikis pada anak akan berdampak buruk, baik yang berkaitan dengan fisik, berupa luka, memar, perdarahan pada anggota tubuh, penyiksaan, cacat seumur hidup bahkan dapat menyebabkan kematian pada anak. Kekerasan verbal pada anak dapat berupa cacian, ancaman, penghinaan, dan kata-kata yang menyakitkan perasaan anak.

Orang tua dalam menerapkan disiplin kepada anak sering tidak memperhatikan keberadaan anak sebagai seorang manusia. Anak sering dibelenggu aturan-aturan orang tua yang tidak rasional dan tanpa menghargai keberadaan anak dengan segala hak-haknya, seperti hak untuk bermain. Hirarki sosial yang diajarkan adalah hirarki otoriter, sewenangwenang. Berbagai kasus kekerasan terhadap anak yang muncul kepermukaan, ternyata tidak hanya terjadi di kota-kota besar di Indonesia tetapi banyak juga terjadi di kota-kota kecil atau daerah yang mash kental dengan budaya ketimuran. Salah satu daerah yang termasuk banyak terjadi kekerasan terhadap anak adalah di Provinsi Maluku khususnya Kota Ambon.

Berdasarkan fenomena yang telah dijelaskan diatas, maka permasalahan yang diangkat oleh penulis untuk dibahas adalah KEBIJAKAN PENANGGULANGAN KEKERASAN TERHADAP ANAK DI KOTA AMBON.

\section{METODE PENELITIAN}

Metode Penelitian adalah tata cara bagaimana suatu penelitian akan dilaksanakan. Mengingat penelitian ini merupakan penelitian hukum, maka metode penelitian yang digunakan adalah metode penelitian hukum. Penelitian hukum merupakan proses untuk menemukan aturan hukum, prinsip-prinsip hukum maupun doktrin-doktrim hukum untuk menjawab isu-isu hukum yang dihadapi (Peter Mahmud Marzuki:35). Untuk menunjang penelitian ini maka penulis mempergunakan metode penelitian:

\section{Jenis Penelitian}

Penelitian tentang Kebijakan Penanggulangan Kekerasan Terhadap Anak di Kota Ambon penelitian Yuridis Empiris. Penelitian Yuridis Empiris adalah suatu metode penelitian hukum yang berfungsi untuk melihat hukum dalam artian nyata dan meneliti bagaimana bekerjanya hukum di lingkungan masyarakat. Dikarenakan dalam penelitian ini meneliti orang dalam hubungan hidup di masyarakat maka metode penelitian hukum 
empiris dapat dikatakan sebagai penelitian hukum sosiologis. Dapat dikatakan bahwa penelitian hukum yang diambil dari fakta-fakta yang ada di dalam suatu masyarakat, badan hukum atau badan pemerintah.

2. Tipe Penelitian

Adapun tipe penelitian yang digunakan adalah deskriptif analitis yaitu memberikan gambaran terhadap objek yang diteliti melalui data atau sampel dan diolah atau dianalisis untuk diambil kesimpulannya (Sugiyono:29).

3. Lokasi Penelitian

Dalam penelitian ini, lokasi yang digunakan sebagai lokasi adalah Kota Ambon, dengan responden sebanyak 30 orang anak yang mengalami kasus kekerasan selama tahun 2017.

4. Sumber Data

Dalam penelitian ini, jenis data yang digunakan adalah data primer yang dihasilkan dari penelitian lapangan yang diperoleh langsung dari responden penelitian yang terkait dengan tindak pidana kekerasan terhadap anak. Dengan mengadakan studi/penelitian kepustakaan akan memperoleh data awal untuk dipergunakan dalam penelitian lapangan, dan data sekunder yang diperoleh dari penelitian kepustakaan terdiri dari:

1. Bahan Hukum Primer, berkaitan dengan masalah yang akan diteliti seperti Undang-Undang Nomor 35 Tahun 2014 tentang Perlindungan Anak.

2. Bahan Hukum Sekunder, merupakan bahan hukum yang memberikan penjelasan dan petunjuk mengenai bahan hukum primer seperti buku-buku referensi, jurnal hukum dan hasil-hasil penelitian karya ilmiah yang relevan dengan penelitian ini.

3. Bahan Hukum Tertier, sebagai bahan hukum penunjang yang mencakup petunjukpetunjuk maupun penjelasan terhadap bahan hukum primer dan sekunder yaitu berupa kamus, ensiklopedia.

5. Teknik Pengumpulan Data

Pengumpulan data yang penulis lakukan dengan dua cara yaitu:

1. Penelitian Kepustakaan, yaitu pengumpulan data sekunder baik berupa peraturan perundang-undangan yang berlaku dan dokumen yang berkaitan dengan objek yang diteliti maupun teori-teori dan asas-asas hukum yang berkaitan dengan materi penelitian.

2. Penelitian Lapangan, yaitu pengumpulan data secara langsung dari pihak-pihak terkait dengan kekerasan terhadap anak agar memperoleh dan menghimpun data primer atau data yang relevan dengan objek yang akan diteliti.

6. Teknik Analisa Data

Data penelitian diolah dan dianalisis secara kualitatif yaitu menganalisa data berdasarkan kualitasnya lalu dideskripsikan dengan menggunakan kata-kata sehingga diperoleh bahasan atau paparan dalam bentuk kalimat yang sistematis dan dapat dimengerti, kemudian ditarik kesimpulan.

\section{HASIL DAN PEMBAHASAN}

\section{Bentuk-bentuk Kekerasan Terhadap Anak}

Persoalan ekonomi, pertengkaran, dan perceraian orang tua sering menjadi sebab terjadinya tindak kekerasan pada anak anak menjadi sasaran kemarahan, kekesalan, dan masalah yang menimpa orang tua. Kekerasan yang terjadi pada anak sulit dilihat seberapa jauh kekerasan yang dilakukan oleh orang tua pada anak. Apakah anak sering menerima 
kekerasan fisik atau kekerasan verbal atau kedua-duanya. Orang-orang atau masyarakat sekitarnya sulit membedakan mana tindakan yang kekerasan atau mana tindakan yang merupakan bagian dari pendidikan.

Orang tua yang memliki tempramen tinggi biasanya mendidik anak-anaknya dengan nada yang tinggi pula. Tidak jarang mereka menjewer atau menampar anaknya atau bahkan membentak dengan kasar. Anak-anak sekalipun tidak mempunyai kebebasan dalam berbuat, anak-anak selalu diatur dan melakukan sesuai menurut kehendak orang tuanya (Rianawati: 3). Anak-anak tidak punya pilihan-pilihan yang mereka sukai. Hidup anak tertekan di rumah orang tua mereka sendiri. Anak-anakpun dipaksa mengerjakan pekerjaan rumah bahkan anak-anak juga dipaksa untuk membantu ekonomi keluarga, seperti menjual koran, mengemis, membantu orang tuanya berjualan,dan sebagainya.

Sangat sulit memantau tindak kekerasan yang dilakukan oleh orang tua. Tindakan hukumanpun sulit menjangkau perilaku keras terhadap anak. Karena tidak ada bukti kekerasan verbal misalnya yang dilakukan oleh orang tua di rumah. Kecuali tindakan kekerasan berat berupa pembunuhan atau tindakan yang menimbulkan cacat pada anak.

Kekerasan yang menimpa anak hadir dalam seluruh jenis hubungan sosial yang dijalaninya, termasuk dalam hubungan keluarga maupun lingkungan sosial. Kekerasan dapat menimpa anak dimana saja baik diruang publik maupun dalam lingkungan sosial. Adapun bentuk-bentuk kekerasan yang sering dialami oleh anak, yaitu:

a. Kekerasan Fisik

Yaitu tindakan yang bertujuan untuk melukai, menyiksa atau menganiaya anak dengan menggunakan anggota tubuh pelaku (tangan, kaki) atau dengan alat-alat lain. Bentuk kekerasan fisik yang dialami oleh anak antara lain: tamparan, pemukulan, penjambakan, mendorong secara kasar, penginjakan, penendangan, pencekikan, pelemparan benda keras, penyiksaan menggunakan benda tajam. Tindakan tersebut mengakibatkan rasa sakit, jatuh sakit dan luka berat.

b. Kekerasan Psikis/Non fisik

Yaitu tindakan yang bertujuan merendahkan anak baik melalui kata-kata maupun perbuatan (ucapan menyakitkan, kata-kata kotor, bentakkan, penghinaan, ancaman) yang menekan emosi anak. Tindakan tersebut mengakibatkan ketakutan, hilangnya rasa percaya diri, hilangnya kemampuan untuk bertindak, rasa tidak berdaya dan penderitaan psikis berat pada anak.

c. Kekerasan Seksual

Adalah kekerasan yang bernuansa seksual, termasuk berbagai perilaku yang tidak diinginkan dan mempunyai makna sesksual yang disebut pelecehan seksual, maupun berbagai bentuk pemaksaan hubungan seksual yang disebut pemerkosaan. Tindakan kekerasan ini bisa diklasifikasikan dalam bentuk kekerasan fisik maupun psikologis.

Berdasarkan penelitian yang dilakukan di Polres P. Ambon \& P.P. Lease, bentuk bentuk kekerasan terhadap anak tahun 2017 dapat dilihat sebagai berikut:

Tabel 1. Penanganan Perkara Anak di unit PPA Polres P. Ambon \& P.P. Lease

\begin{tabular}{|c|l|c|}
\hline No. & \multicolumn{1}{|c|}{ Jenis Tindak Pidana } & Jumlah Kasus \\
\hline 1 & Kekerasan Terhadap Anak & 45 \\
\hline 2 & Percabulan Terhadap Anak & 22 \\
\hline 3 & Persetubuhan Terhadap Anak & 34 \\
\hline 4 & Aborsi & 5 \\
\hline
\end{tabular}

\section{Penanggulangan Kekerasan Terhadap Anak di Kota Ambon}


Kekerasan terhadap anak baik yang dilakukan secara fisik maupun non fisik/psikis membuat anak menjadi pribadi yang lebih tertutup dan diselimuti rasa takut, tidak hanya dalam keluarga tetapi juga dalam pergaulannya dengan lingkungan sosial. Tidak semua kekerasan yang dialami anak, membuat anak menjadi pribadi yang tertutup, ada juga anak yang menjadi pemberontak karena kekerasan yang dialaminya. Dikota Ambon, kekerasan terhadap anak yang dilakukan adalah kekerasan fisik seperti menampar, memukul ataupun menendang anak dan kekerasan non fisik/psikis seperti memaki, dan membuat malu anak. Oleh karena itu perlu penanganan dan penanggulangan kekerasan terhadap anak dalam beberapa tahapan, antara lain:

\section{Tahap Preempif}

Yang dimaksud dengan preemptif adalah upaya-upaya awal yang dilakukan untuk mencegah terjadi tindak pidana. Pada tahapan ini, peran orang tua maupun keluarga sangat berpengaruh penting. didikan untuk melindungi anak dari kekerasan yang dapat terjadi dilakukan dengan memberikan contoh yang baik kepada anak, mendidik anak tentang berperilaku yang sopan baik orang lain maupun untuk diri sendiri, nasehat yang diberikan kepada anak harus bersifat edukatif yang membuat anak lebih menghargai orang lain sehingga anak terhindar dari kekerasan yang membahayakan dirinya sendiri, selain itu pengawasan terhadap anak perlu ditingkatkan.

Di kota Ambon, berdasarkan pengamatan pada beberapa wilayah fungsi keluarga dan orang tua sebagai unit terkecil dalam masyarakat mulai hilang. Orang tua lebih sibuk dengan urusannya masing-masing dan sering mengabaikan anak. Sehingga proses mendidik, mengasuh serta mengawasi anak terabaikan. Tidak jarang, anak juga merupakan korban kekerasan orang tuanya sendiri. Anak sering mengalami kekerasan verbal dimana panggilan kepada anak menjadi "kebun binatang" yang seenaknya saja diucapkan oleh orang tua maupun orang lebih tua yang bertemu dengan anak. Pola asuh serta pengawasan yang kurang ketat terhadap anak oleh orang tua merupakan salah satu penyebab terjadinya kekerasan yang dialami oleh anak.

2. Tahap Preventif

Tahapan ini merupakan upaya pencegahan anak terhadap tindak pidana yang dapat membahayakan diri anak tersebut. Pada tahapan ini, keterlibatan orang tua, guru, pemuka agama, pemuka masyarakat sangat membantu untuk mencegah terjadinya tindak pidana terhadap anak. Upaya preventif dapat dilakukan baik dalam bentuk sosialisasi yang dilaksanakan di sekolah-sekolah, tempat-tempat bermain anak, maupun melalui sarana kegiatan keagamaan sebagai bentuk pencegahan untuk meminimalisir kekerasan yang dilakukan terhadap anak.

\section{Tahap Represif}

Pada saat terjadi kekerasan terhadap anak, yang menyebabkan anak menjadi korban, maka upaya yang dilakukan menggunakan sarana penal. Undang-Undang Nomor 35 Tahun 2014 tentang Perubahan atas Undang-Undang Nomor 23 Tahun 2002 tentang Perlindungan Anak.

Peranan Kepolisian dalam mengungkap setiap kasus tindak pidana yang membuat anak menjadi korban, sangat membantu dalam melakukan proses penegakan hukum terhadap anak. Profesionalisme aparat penegak hukum dalam upaya perlindungan terhadap anak dapat diharapkan dapat memberikan efek jera bagi pelaku tindak pidana.

\section{KESIMPULAN}

Berdasarkan penelitian yang dilakukan, maka dapat disimpulkan kekerasan terhadap anak terdiri dari beberapa bentuk yang umum yaitu Kekerasan fisik, kekerasan 
psikis/non fisik dan kekerasan seksual. Untuk kota Ambon, bentuk kekerasan terhadap anak antara lain kekerasan terhadap anak, percabulan terhadap anak, persetubuhan terhadap anak, dan aborsi. Dalam upaya penanggulangan kekerasan terhadap anak digunakan dalam 3 tahap yaitu preemtif, preventif dan represif. Upaya preempif dapat dilakukan dari lingkungan keluarga oleh orang tua dengan pengawasan terhadap semua kegiatan anak. Upaya preventif dapat dilakukan melalui edukasi dan sosialisasi baik yang dilakukan baik oleh orang tua, guru maupun tokoh agama dan tokoh masyarakat. Sedangkan upaya represif dilakukan menggunakan hukum pidana oleh aparat penegak hukum.

\section{REFERENSI}

Arief, B. N. (1996). Kebijakan Legislatif Dalam Penanggulangan Kejahatan Dengan Pidana Penjara. Semarang: UNDIP Publisher.

Dellyana, S. (1988). Wanita dan Anak di Mata Hukum, Cet. Ke-1. Yogyakarta: Liberty.

Huraerah, A. (2006). Kekerasan Terhadap Anak. Bandung: Penerbit Nuansa.

Ibrahim, J. (2006). Teori dan Metodologi Penelitian Hukum Normatif. Malang: Bayumedia Publishing.

Marzuki, P. M. (2006). Penelitian Hukum. Jakarta: Kencana Prenada.

Rianawati. (2015). Perlindungan Hukum Terhadap Kekerasan Pada Anak. Raheema: Jurnal Studi Gender dan Anak, 1-13.

Rozak, P. (2013). Kekerasan Terhadap Anak Dalam Rumah Tangga Perspektif Hukum Islam. Sawwa, Volume 9, No. 1, 45-70.

Sihombing, J. (2005). Kekerasan Terhadap Masyarakat Marjinal . Yogyakarta: Penerbit Narasi.

Soekanto, S. (2007). Faktor-faktor yang Mempengaruhi Penegakan Hukum . Jakarta: Grafindo Persada.

Sumiarni, E. (2000). Perlindungan Terhadap Anak di Bidang Hukum. Yogyakarta: Universitas Atmajaya Publisher. 